\title{
杭と架構を一体とした弾性解析による杭基礎の水平力作用時の
}

応力一変形系 (一層地盤の場合)

\section{SYSTEMATIC ELASTIC THEORY ON STRESS AND DEFORMATION OF PILE FOUNDATION WITH SUPERSTRUCTURE ON SINGLE LAYER GROUND SUBJECTED TO LATERAL LOAD}

\author{
中澤瑤子* \\ Yohko NAKAZAWA
}

\begin{abstract}
Up to the present, the lateral stress of pile foundations have been usually designed without superstructure so, from the strict theoretical point of view, the stress and deformation are not considered to be correct. This paper expressed the systematic theory of pile foundation with superstructure by elastic analysis on single layer ground under lateral load.

1. General characteristics of pile foundation are explained not by absolute value but by stress per unit deformation.

2. General characteristics are controlled by non dimensional rotation. $\theta \mathrm{o} /($ yo $\beta$ )or $\theta \mathrm{o} /($ yo $\eta)$.

3. Non dimensional rotation is related with $\omega$ :the restraint factor of rotation.

$\omega$ :consists of $\mathrm{EcKg}(\mathrm{kNm})$ :rigidity of ground beam , $\mathrm{E}_{\mathrm{p}} \mathrm{I}_{\mathrm{p}}\left(\mathrm{kNm}^{2}\right)$ :bending rigidity of pile and $\beta$ or $\eta$ :constant of ground characterstics.

4. The stress and deformation of pile foundation are able to be easily calculated using the results of this paper.
\end{abstract}

Keywords: pile foundation, superstructure, systematic theory, lateral load, restraint factor of rotation, non dimensional rotation, non dimensional pile length, single layer ground, elastic analysis, 杭基礎、上部架構、理論系、水平力、回転拘束度、無次元回転角、無次元杭長さ、一層地盤、弹性解析

1.はじめに

現在、一般的な建築物では、上部架構 (以下、架構と略称)をもっ た杭基礎 (以下、杭基磷と略称)の水平力作用時の設計において、杭 は架構と切り離され、杭頭は回転しないと考えて設計が行われるこ とが多い1。しかし、架構は水平力を受けて水平に変位するだけで なく各節点は回転角を生じる。杭と基礎梁、1 階柱で構成された基 礎節点も例外ではなく2)、基礎に固定状態に埋め込まれている杭頭 は基礎と同一の回転を生じる。また、杭基礎の回転角は加力方向に 沿って基礎の両側に基礎梁がある中基礎では小さいが、片側だけに 基整梁がある隅基礎では大きい。このことが架構の中基礎と隅基礎 の杭頭部での水平力分担や曲げモーメントの相違の一因となる。し たがって、整合性のある応力や変形を得るためには杭は架構と一体 として応力変形を求める必要がある。これまでに筆者らは、杭に弾 性支承梁理論を適用し、架構部材に弾性線材としてのたわみ角法の 式 (3) 適用し、杭と架構の精算法による弹性一体解析 ${ }^{4)}$ を数多く行っ てきた。この弾性解析による結果として、杭基礎の応力・変形にと って、基礎が回転することと基礎梁によって全ての杭頭水平変位yo が一定に拘束されることの 2 点は無視できないことがわかった。ま た、その後の検討で、この特性は杭の種類を問わないものであるこ ともわかった。そこで、本報は、杭と架構を一体とした精算法によ
る弾性解析によって判明した杭基礎の応力・変形特性を、杭種を問 わないひとつの系として整理して報告する。1柱 1 杭形式で杭頭が 基礎に剛結された杭基礎である。地盤は水平反力係数 $\mathrm{k}_{\mathrm{h}}$ が一定值の 場合 (以後、 $\beta$ 型地盤と呼ぶ)およびk で増大寸る場合 (同・ $\eta$ 型地盤)である。これらの地盤を共に一層地 盤と称しておく。さらに、この忘力・変形系に基づいた簡単な杭基 礎の設計法を示した。

本報は弾性解析による結果であるが、杭基礎の設計は弾性状態だ けでなく地盤および杭体の塑性化も考えて進めなければならないこ とは当然である。筆者らも、地盤および杭体の塑性化を段階的に進 めて解析を行い、その結果を重わあわせて杭基礎の終局耐力と変形

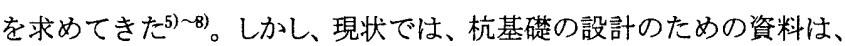
弹性域に限っても、筆者らによる提案 ${ }^{9}$ などを除くと特には見あた らない。まず、弾性状態での杭基礎の挙動を架構の剛性を考慮して 把握することが、ひいては塑性状態での杭基礎の設計を適切に行う 基本になると考えたので、本報を示した。

\section{2. 架構と一体とした杭基礎の応力変形解析法の概要}

架構と杭基礎の一体解析は、壁のない柱梁のみで構成されたラー メン架構を対象とし、部材は曲げ剛性のみを考慮した線材として扱

*㛦アルマチュール構造設計事務所 工博 Armature Construction Bureau., Dr. Eng. 
う。解法は、弾性支承梁理論解による杭頭部の応力変形式と、基磷 に集まる架構部材のたわみ角法の式とで応力釣合式をたて、その他 の各層の節点方程式、層方程式および全てのyoが一定の条件式とで 多元連立にコンピュータで解くものであって、架構の節点角や水平 変位、材端曲げモーメント、せん断力さらに杭頭の曲げモーメント Mo、水平力Qo、水平変位yo、回転角 $\theta$ o が得られ、これらを弾性支 承梁理論による杭の各哚度での解に戻すことによって杭の地中部に おける応力変形も得られる。なお、基礎梁の軸方向伸縮は無視し、 また基礎閒の相対沈下はないものとした。以後、この精算解析を一 体解析と略称寸る。

一体解析のための架構モデルは 1 層 3 スパンの鉄筋コンクリート ラーメン架構(部材のヤング係数 $\left.\mathrm{Ec}=2,100 \mathrm{kN} / \mathrm{cm}^{2}\right)$ を採用した。しか し、本報の結果は架構のスパン数や層数に関係しない一般特性であ る。簡単な架構を選んだ理由は、これまでに多層架構での 1 階より 上層の剛性が杭基礎応力に与える影響は少ないことがわかっており 10)、また予備的な解析で、基礎間の相対沈下がない場合の杭基磷の 回転角はほぼ隅基礎とそれ以外の中基礎にまとめられることがわか

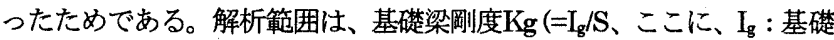
梁断面 2 次モーメント、 $\mathrm{S}:$ スパン長さ)は0.0025，0.005、0.01、0.02、 $0.03 、 0.05 \mathrm{~m}^{3}$ 6 種類 (ほほ梁断面 $0.3 \times 0.6 \sim 0.6 \times 2.0$ (単位 : $\mathrm{m}$ )) 、 1 階柱剛度 $\mathrm{Kc}\left(=\mathrm{I}_{\mathrm{c}} / \mathrm{h}\right.$ 、ここに、 $\mathrm{I}_{\mathrm{c}}$ : 柱断面 2 次モーメント、 $\mathrm{h}$ : 階 高) は0.005、0.007 $\mathrm{m}^{3} の 2$ 種類 (ほほ柱断面 $0.6 \times 0.6 \sim 0.8 \times 0.8$ (単 位 $: \mathrm{m}))$ である。2 階梁剛度 $\mathrm{K}_{\mathrm{b}}\left(=\mathrm{I}_{\mathrm{b}} / \mathrm{S} 、 こ こ に 、 \mathrm{I}_{\mathrm{b}}: 2\right.$ 階梁断面 2 次 モーメント)は杭基礎の応力にさほど影響しないため $0.004 \mathrm{~m}^{3} の 一$ 定値とした。杭は場所打ちコンクリート杭（杭部材のヤング保数 $\mathrm{E}_{\mathrm{p}}=$ $2,100 \mathrm{kN} / \mathrm{cm}^{2}$ ) で杭径1.0、1.2、1.4mの 3 種類(杭曲け用性 $\mathrm{E}_{\mathrm{p}} \mathrm{I}_{\mathrm{p}}=103 \sim$ $396 \times 10^{4} \mathrm{kNm}^{2}$ ) およひPC杭（杭部材のヤング係数 $\mathrm{E}_{\mathrm{p}}=4,000 \mathrm{kN} / \mathrm{cm}^{2}$ ) で杭径0.6、0.8mの 2 種類 $\left(\mathrm{E}_{\mathrm{p}} \mathrm{I}_{\mathrm{p}}=20 \sim 62 \times 10^{4} \mathrm{kNm}^{2}\right)$ 、杭長さは 4 〜 $20 \mathrm{~m}$ の任意の長さとし、杭径に対して杭長さが短すぎる場合は解析 の範囲から除外した。杭基碄は 1 柱 1 杭形式で架構内では同一の杭 種、杭径、杭長さを選えだ。地盤は、 $\beta$ 型地盤は $\mathrm{k}_{\mathrm{h}}=5,000 、 10,000$ 、 $20,000 \mathrm{kN} / \mathrm{m}^{3}$ の 3 種類 $\left(\beta \doteqdot 0.13 \sim 0.4 \mathrm{~m}^{-1}\right.$ にあたる)および $\eta$ 型地盤 は $\mathrm{n}_{\mathrm{h}}=1,000 、 2,200 、 6,500 \mathrm{kN} / \mathrm{m}^{3}$ の 3 種類 $(\eta \doteqdot 0.2 \sim 0.5 \mathrm{~m} \cdot 1$ にあた る) とした。上述の範囲内で適宜組み合わせて約 220 例の一体解析を 行った。解析を行った範囲での杭の無次元長さは $\beta \mathrm{L}=1.3 \sim 5.0 、 \eta \mathrm{L}$ $=1.5$ 7.2である。

\section{3. 半無限長さの杭基礎の特性}

架構を支持する杭基礎は、互いに基礎梁で椠がれ、杭頭水平変位

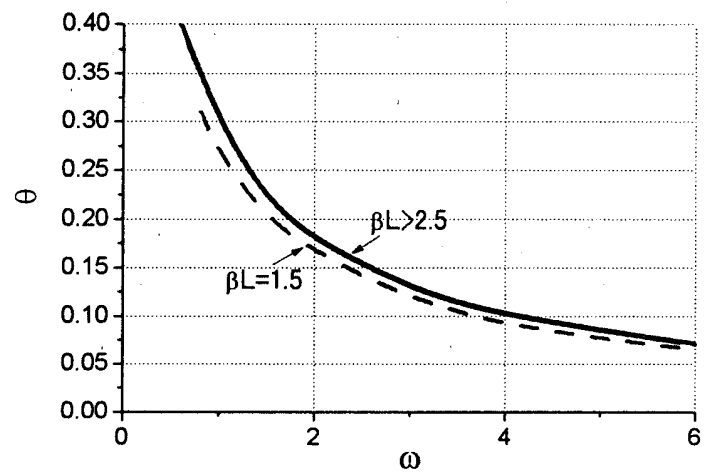

図 $1 \quad \boldsymbol{\theta}-\boldsymbol{\omega}$ 関係 $(\beta$ 型地盤) yoが一定に拘束されているため、杭基礎の応力や変形の一般特性は、 その絶対量ではなく単位水平変位あたりの値に現れる。そこで、杭 長さが十分に長く半無限長さとみなせる場合について、杭の弾性支 承梁理論式 $\left(E_{\mathrm{p}} \mathrm{I}_{\mathrm{p}} \mathrm{d}^{4} \mathrm{y} / \mathrm{dx}^{4}+\mathrm{k}_{\mathrm{h}} \mathrm{D} \times \mathrm{y}=0\right.$ 、ここに、 $\mathrm{E}_{\mathrm{p}} \mathrm{I}_{\mathrm{p}}$ : 杭曲け剛性、 $\mathrm{k}_{\mathrm{h}}$ : 地船の水平反力係数、 $\mathrm{D}:$ 杭径、 $\mathrm{y}:$ 水平变位、 $\mathrm{x}:$ 深さ)における杭 頭での水平力Qo、曲げモーメントMoの式を求め、これを単位水平 変位あたりの式Qo/yo、Mo/yoの形で表現してみた。弾性支承梁理論 の解法は、杭を長さ方向に区分し、区分間の平均 $\mathrm{k}_{\mathrm{h}}$ 值を用い、区分 の境界条件を一致させて、杭頭部にQo、Moが作用し、杭先端はピ ンと仮定して解く方法である。この解法を杭の区分解析と称してお く。Qo、Mo式の記載は省略し、Qo/yo、Mo/yoの形で示すと、 $\mathrm{k}_{\mathrm{h}}$ が 樑さに関倸なく一定の $\beta$ 型地盤の場合は(1)および(2)式であり、 $\mathrm{k}_{\mathrm{h}}$ が深さに比例する $\eta$ 型地盤の場合 $\left(\mathrm{k}_{\mathrm{h}}=\mathrm{n}_{\mathrm{h}} \times \mathrm{x} / \mathrm{D} 、 こ こ に 、 \mathrm{n}_{\mathrm{h}}\right.$ ：定数 $)$

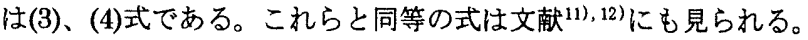
ここに、 $\beta=\left(\mathrm{k}_{\mathrm{h}} \mathrm{D} /\left(4 \mathrm{E}_{\mathrm{p}} \mathrm{I}_{\mathrm{p}}\right)\right)^{0.25} 、 \eta=\left(\mathrm{n}_{\mathrm{h}} /\left(\mathrm{E}_{\mathrm{p}} \mathrm{I}_{\mathrm{p}}\right)\right)^{0.2}$ である。同式の俰数 $\theta \mathrm{o} /(\mathrm{yo} \beta)$ および $\theta \mathrm{o} /(\mathrm{yo} \eta)$ を $\theta$ で記号化する。 $\theta$ は杭頭の無次元回転 角にあたる。杭基礎のQo/yo、Mo/yo値は $\theta$ によって变化することが わかる。

$$
\begin{aligned}
& \mathrm{Qo} / \mathrm{yo}=(2-\theta \mathrm{o} /(\mathrm{yo} \beta)) \times 2 \mathrm{E}_{\mathrm{p}} \mathrm{I}_{\mathrm{p}} \beta^{3} \\
& \mathrm{Mo} / \mathrm{yo}=(-1+\theta \mathrm{o} /(\mathrm{yo} \beta)) \times 2 \mathrm{E}_{\mathrm{p}} \mathrm{I}_{\mathrm{p}} \beta^{2} \\
& \mathrm{Qo} / \mathrm{yo}^{2}=(0.54-0.5 \theta \mathrm{o} /(\mathrm{yo} \eta)) \times 2 \mathrm{E}_{\mathrm{p}} \mathrm{I}_{\mathrm{p}} \eta^{3} \\
& \mathrm{Mo} / \mathrm{yo}^{2}=(-0.5+0.75 \theta \mathrm{o} /(\text { yo } \eta)) \times 2 \mathrm{E}_{\mathrm{p}} \mathrm{I}_{\mathrm{p}} \eta^{2}
\end{aligned}
$$

一体解析の結果、 $\theta$ 值は、基礎に集まる基礎梁の曲げ剛度の和 (隅 基䃈 : EcKg、中基整 : $\Sigma \mathrm{EcKg}$ ) と杭の曲け剛性 $\mathrm{E}_{\mathrm{p}} \mathrm{I}_{\mathrm{p}}$ および $\beta$ あるい はクの比で表される無次元量と相関性がみられた。そこで、この無 次元量を(5)〜(8)式で表現し、 $\omega$ で記号化した。 $\omega$ を杭頭の回転拘束 度と称しておく。

$\beta$ 型地盤における杭頭回転拘束度 $\omega$

隅基礎 : $\omega=\mathrm{EcKg} /\left(\mathrm{E}_{\mathrm{p}} \mathrm{I}_{\mathrm{p}} \beta\right)$

中基礎 : $\omega=1.6 \Sigma \mathrm{EcKg} /\left(\mathrm{E}_{\mathrm{p}} \mathrm{I}_{\mathrm{p}} \beta\right)$

$\eta$ 型地盤における杭頭回転拘束度 $\omega$

隅基礎 : $\omega=\mathrm{EcKg} /\left(\mathrm{E}_{\mathrm{p}} \mathrm{I}_{\mathrm{p}} \eta\right)$

中基礎 : $\omega=1.6 \Sigma \mathrm{EcKg} /\left(\mathrm{E}_{\mathrm{p}} \mathrm{I}_{\mathrm{p}} \eta\right)$

$\omega$ を表す要素に 1 階柱剛度を含めなかった理由は、解析結果をみ ると、 $\theta$ 值に対して 1 階柱剛度はほぼ一定值として関与していたた めである。また、 $\theta$ 値は隅基礎では大きく中基礎では小さかった。 この原因が、基礎梁が片側のみにある隅基礎に比べ両側にある中基

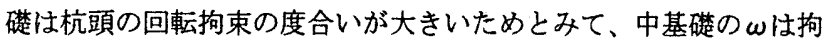

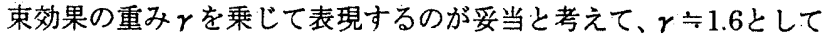

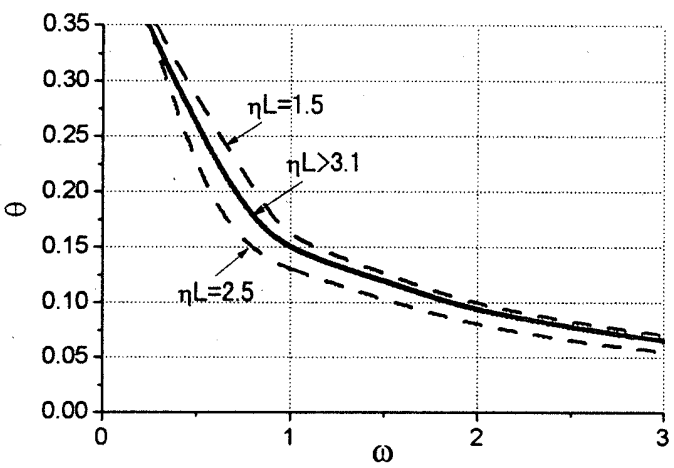

図 $2 \quad \theta-\omega$ 関倸 $(\eta$ 型地盤 $)$ 
中基礎の $\omega$ を表現した。これによって、中基礎と隅基礎での異なる $\theta$ 值の変化を一つの曲線に表現できた。これを $\theta-\omega$ 関係として、 図 1 に $\beta$ 型地盤の場合を、図 2 に $\eta$ 型地盤の場合をそれぞれ実線で

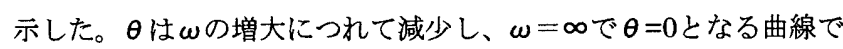
ある。同曲線は $\beta$ 型地盤では $\omega \fallingdotseq 1.8 、 \eta$ 型地盤では $\omega \doteqdot 0.8$ で急折

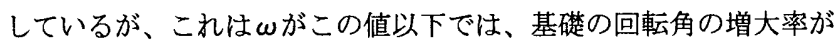
增し、杭頭の回転角が杭頭ピン $(\omega=0)$ の場合の回転角に近づくた めである。一体解析を行った範囲について $\omega$ 值を(5) (8)式で求める と、隅基礎：0.1〜13.0、中基礎：0.3〜40.0であった。なお、杭お よび基礎梁剛度が均一な架構では、 $\Sigma \mathrm{EcKg}=2 \mathrm{EcKg}$ であるため、中 基礎の $\omega=1.6 \Sigma \mathrm{EcKg} /\left(\mathrm{E}_{\mathrm{p}} \mathrm{I}_{\mathrm{p}} \beta\right)$ は $\omega=3.2 \mathrm{EcKg} /\left(\mathrm{E}_{\mathrm{p}} \mathrm{I}_{\mathrm{p}} \beta\right)$ と読替えられ るので、中基礎の $\omega$ 值は隅基礎の $\omega$ 值の3.2倍となる。

$$
\begin{aligned}
& \mathrm{M}_{\mathrm{m}}=\mathrm{c} \times \mathrm{Qo} / \beta \\
& \mathrm{M}_{\mathrm{m}}=\mathrm{c} \times \mathrm{Qo} / \eta
\end{aligned}
$$

一方、杭の地中部最大曲げモーメント $\mathrm{M}_{\mathrm{m}}$ は、変形と関連づけた式 では表現しにくいので、一体解析で得た $\mathrm{M}_{\mathrm{m}}$ 値を、同様に一体解析で 得たQo值との関係として(9)、(10)式で表現して同式の係数 $\mathrm{c}$ を得 た。係数 $\mathrm{c} も \omega$ とよい相関性があり、c- $\omega$ 関倸は $\beta$ 型地盤では図 3 の実線、 $\eta$ 型地盤では図 4 の実線であった。一体解析で得た $\mathrm{M}_{\mathrm{m}}$ の発 生梁さ $\mathrm{L}_{\mathrm{m}}$ を無次元量 $\beta \mathrm{L}_{\mathrm{m}}$ および $\eta \mathrm{L}_{\mathrm{m}}$ で表現すると、これらは って変化して抢り、 $\beta \mathrm{L}_{m}-\omega$ 関係は図 5、 $\eta \mathrm{L}_{m}-\omega$ 関係は図6の実線と なった。 $\omega=0$ での $\beta \mathrm{L}_{\mathrm{m}}$ および $\eta \mathrm{L}_{\mathrm{m}}$ は杭頭ピンの場合 ( $\beta$ 型地盤 0.79 および $\eta$ 型地盤1.32)に一致し、 $\omega$ の增大につれて大きくなり、 $\omega=$ ので $\theta 0=0$ の場合の值（同1.57および同2.15)に一致する。

以上、架構を考慮した半無限長さの杭基礎の応力・変形特性を、 杭頭の回転拘束度 $\omega$ との関係として定性的かつ定量的に明らかにし た。

\section{4. 有限長さ杭基礎の特性}

杭長さを半無限長さ（“長い杭”とも言う）とみなせない範囲は 文献 ${ }^{13)}$, 14), 15)などに“中間長さの杭”、“短い杭”などとして記され ているが根拠が判然としない。そこで、任意の長さの杭について杭

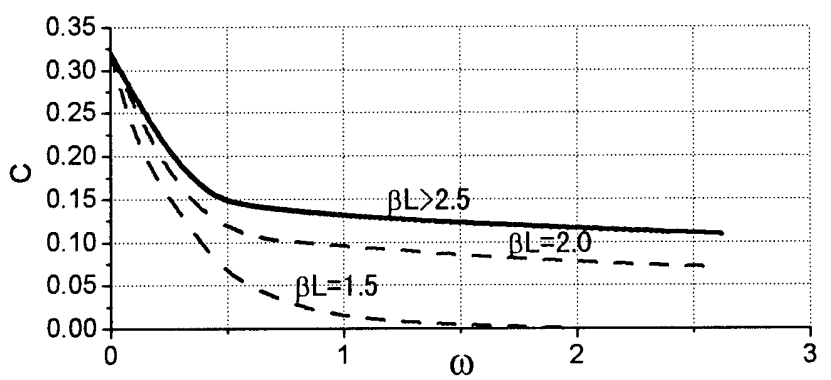

図 $3 \quad C-\omega$ 関係 $(\beta$ 型地盤)

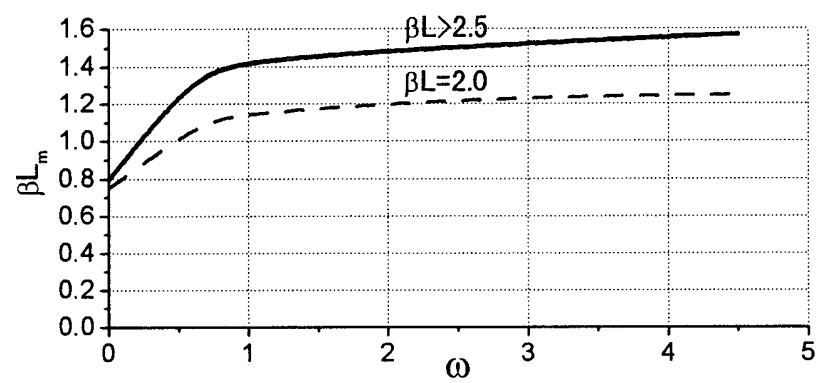

図 $5 \quad \beta \mathrm{L}_{\mathrm{m}}-\omega$ 関係 $(\beta$ 型地盤)
の区分解析を行った。この結果、杭頭の态力/変形は(11) (14)式の 形であり、同式の倸数Koz、Koy、Kom と無次元杭長さ $\beta \mathrm{L} の$ 関係は

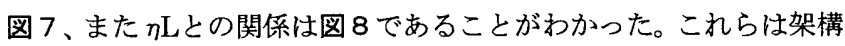
の有無に関係しない式であり係数值である。また、同式において基 礎が回転しない場合 $(\theta 0=0)$ を(15)、(16)式として示した。なお、 Koz、Koy、Komと $\beta$ Lの関係については、すでに文献 $\left.{ }^{16}\right)$ に類似の值 が示されており、本報の杭の区分解析においても同じ結果であった。

$$
\begin{aligned}
& \mathrm{Qo} / \mathrm{yo}=(2 \mathrm{Koz}-\mathrm{Koy} \times \theta \mathrm{o} /(\mathrm{yo} \beta)) \times 2 \mathrm{E}_{\mathrm{p}} \mathrm{I}_{\mathrm{p}} \beta^{3} \\
& \mathrm{Mo} / \mathrm{yo}=(-\mathrm{Koy}+\mathrm{Kom} \times \theta \mathrm{o} /(\mathrm{yo} \beta)) \times 2 \mathrm{E}_{\mathrm{p}} \mathrm{I}_{\mathrm{p}} \beta^{2} \\
& \mathrm{Qo} / \mathrm{yo}^{2}=(2 \mathrm{Koz}-\mathrm{Koy} \times \theta \mathrm{o} /(\mathrm{yo} \eta)) \times 2 \mathrm{E}_{\mathrm{p}} \mathrm{I}_{\mathrm{p}} \eta^{3} \\
& \mathrm{Mo} / \mathrm{yo}=(-\mathrm{Koy}+\mathrm{Kom} \times \theta \mathrm{o} /(\mathrm{yo} \eta)) \times 2 \mathrm{E}_{\mathrm{p}} \mathrm{I}_{\mathrm{p}} \eta^{2} \\
& \mathrm{Mo} / \mathrm{yo}=-2 \mathrm{KoyE}_{\mathrm{p}} \mathrm{I}_{\mathrm{p}} \beta^{2} \\
& \mathrm{Mo} / \mathrm{yo}=-2 \mathrm{KoyE}_{\mathrm{p}} \mathrm{I}_{\mathrm{p}} \eta^{2}
\end{aligned}
$$

同図から、 $\beta$ 型地盤ではほぼ $\beta L>2.5$ の範囲で無次元杭長さが大き くなっても倸数 Koz,Koy,Kom の值が変化せず一定值であり、かつ 半無限長さ杭の係数值 ((1)、(2)式参照) と一致することから、この範 囲が半無限長さの範囲(長い杭)であるといえる。また、 $\eta$ 型地盤で は $\eta \mathrm{L}>3.1$ の範囲で同樣に保数值が半無限長さ杭の場合 ((3)、(4)式参 照) と一致した。したがって $\beta \mathrm{L}<2.5$ や $\eta \mathrm{L}<3.1$ の範囲が有限長さ杭 の範囲とわかる。この範囲で(15)、(16)式をみると、 $\beta$ 型地盤にお ける $1.6<\beta L<2.5$ 範囲では倸数Koy值が長い杭の場合よりも小さ いため Mo/yo值も小さくなり、 $\beta \mathrm{L}<1.6$ の範囲では係数Koy值は長い 杭の場合よりも大きいためMo/yo值は大きくなる。ただし、これら は連続性をもって変化するためこれらの境界付近での值は等しい。 このように $\theta \mathbf{o}=0$ の場合の杭頭曲げモーメントの大きさに注目すれ ば、有限長さ杭はおよそ $\beta \mathrm{L}<1.6$ の短い杭の範囲と、1.6 $<\beta \mathrm{L}<2.5$ の中間長さの杭の範囲に分けられる。同様に、 $\eta$ 型地盤では、短い 杭の範囲 : $\eta \mathrm{L}<2.0$ 、中間長さ杭の範囲 : $2.0<\eta \mathrm{L}<3.1$ である。な お、これは弾性理論における区分であって塑性域における区分 ${ }^{13), 14)}$ を云々するものではない。

有限長さ杭基礎においても、(11)〜(14)式で明らかなように、杭頭 忘力/変形は $\theta$ によって変化する。一体解析を行って $\theta$ 值を得、そ

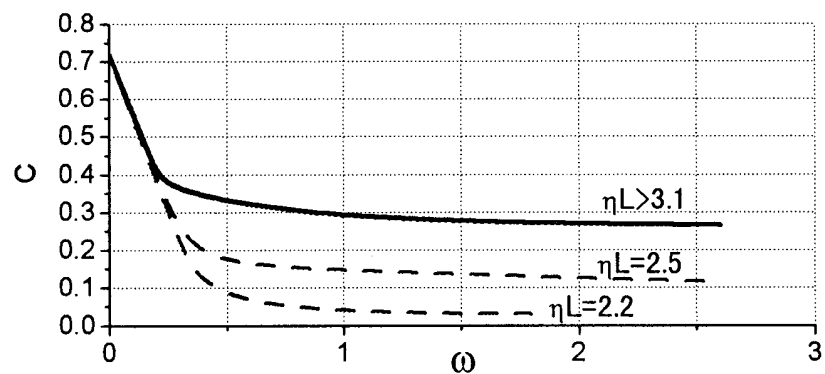

図 $4 \quad C-\omega$ 関倸 $(\eta$ 型地盤 $)$

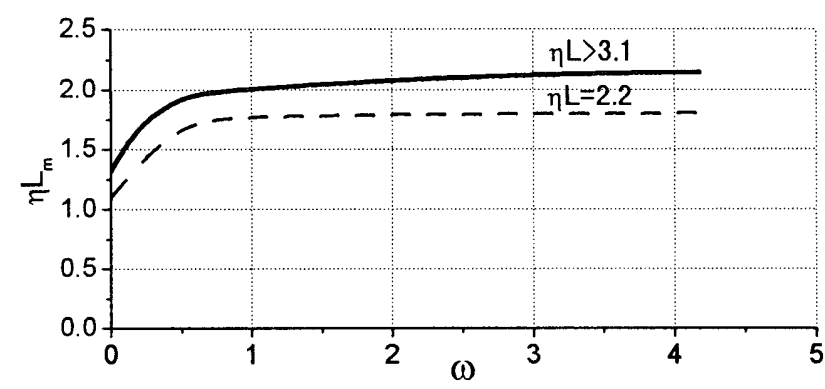

図 $6 \eta \mathrm{L}_{m}-\omega$ 関係 $(\eta$ 型地盤 $)$ 
の值と前出の(5)〜 (8)式で求めたそれぞれの杭基礎の $\omega$ 值との関保 を調べると、架構、杭などの条件に関係なく、隅基礎と中基礎の $\theta$ 一関係は一つの曲線となった。これを、図1、図2にいくつかの 有限長さ杭基礎の $\theta-\omega$ 関係として破線で併記した。なお、無次元 杭長さ $\beta \mathrm{L}>2.5$ あるいは $\eta \mathrm{L}>3.1$ の範囲における $\theta-\omega$ 関係は半無 限長さ杭基礎の場合 (同図の実線)に一致した。また、 $\omega$ 一定の場合 の $\theta-\beta \mathrm{L}$ 関係を図 9、 $\theta-\eta \mathrm{L}$ 関係を图 1 ○に示した。 $\omega$ 一定の場 合、日はそれぞれ、杭長さの区分にほぼ従って変化している。

一体解析で得られた有限長さ杭基礎の $\mathrm{M}_{\mathrm{m}}$ 值を前出の(9)(10)式で 整理すると、c- $\omega$ 関係は前出の図 3、図4k破線で併記した関係と なった。 $\beta \mathrm{L}>2.5$ あるいは $\eta \mathrm{L}>3.1$ における $\mathrm{c}-\omega$ 関係は半無限長さ 杭基礎の場合(同図の実線)に一致した。cの值は、ほぼ $\omega>1.0$ 範 囲で山一定の場合、 $\beta \mathrm{L}$ あるいは $\eta \mathrm{L}$ が小さいほど小さく、 $\beta \mathrm{L} \div 1.5$ 、 $\eta \mathrm{L} \doteqdot 2.2$ でc=0すなわち $\mathrm{M}_{\mathrm{m}}=0$ となり、それ以上短い杭では、杭全長 にわたって曲げモーメントの符号が杭頭部と同じになるため、 $\mathrm{M}_{\mathrm{m}}$ 值としては確認できなくなった。 $\mathrm{M}_{\mathrm{m}}$ の発生深さ $\mathrm{L}_{\mathrm{m}}$ も一体解析で判 明したので、それを無次元量 $\beta \mathrm{L}_{\mathrm{m}}$ あるいは $\eta \mathrm{L}_{\mathrm{m}}$ で表現すると、これら もまた、 $\omega$ との間に一義的な関係がみられ、前出の図 5 およひ图 6 に破線で併記した曲線となった。 $\beta \mathrm{L}$ るいは $\eta \mathrm{L}$ 一定の場合、 $\omega=0$ での $\beta \mathrm{L}_{\mathrm{m}}$ あるいは $\eta \mathrm{L}_{\mathrm{m}}$ 值は、杭頭ピンの場合の值に一致し、 $\omega$ が増 大するにつれて増大して、 $\omega=\infty て ゙ ~ \theta 0=0$ の場合の値に一致する。同 図において、 $\beta$ 型地盤では $\omega \doteqdot 0.5 \sim 0.8 、 \eta$ 型地盤では $\omega \doteqdot 0.2 \sim 0.5$

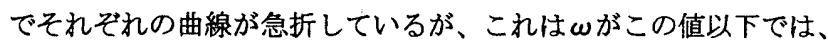
$\omega$ が小さいほど杭頭の回転角の増大率が大きくなって $\mathrm{M}_{\mathrm{m}}$ の值が杭 頭ピンの場合の值に近づくためである。この急折点の $\omega$ 值が杭頭部 の $\theta-\omega$ 関係における值よりもかなり小さいのは、 $\mathrm{M}_{\mathrm{m}}$ の発生深さが 杭頭から離れているため、杭頭の回転角の増大率による地中部の応

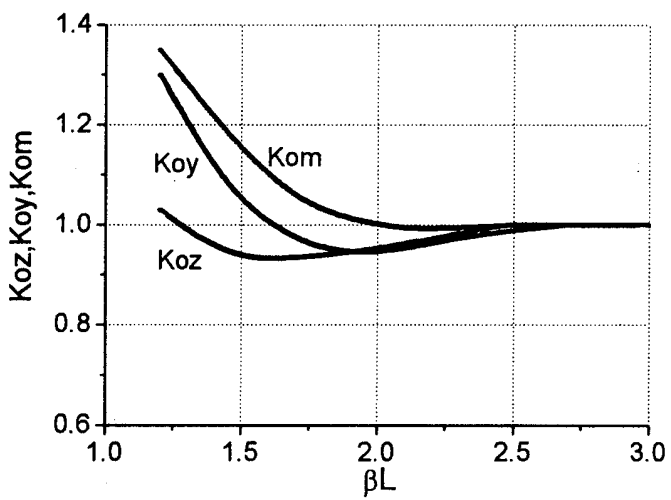

図 7 Koz、Koy、Kom $-\beta L$ 関係 $(\beta$ 型地艋 $)$

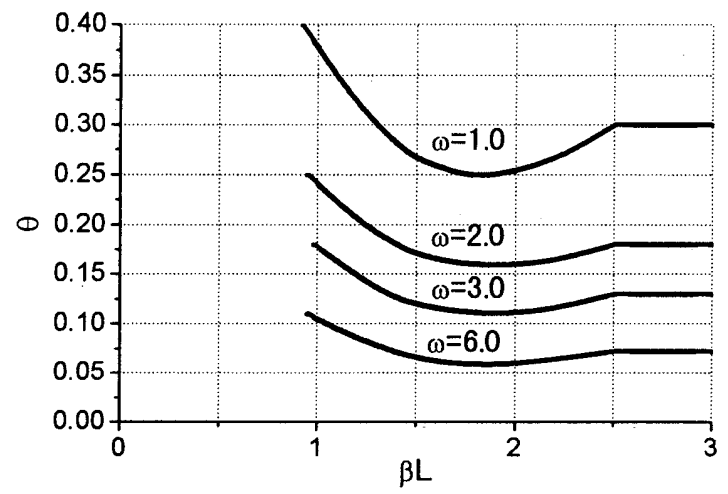

図 9 $\theta-\beta \mathrm{L}$ 関係 $(\beta$ 型地盤 $)$
カ・変形の変化が杭頭部に比べて遅れるためである。

以上、有限長さ杭基礎の応力・変形特性を、杭頭回転拘束度 $\omega$ と 無次元杭長さ $\beta \mathrm{L}$ あいは $\eta \mathrm{L}$ と関係として、定性的かつ定量的に 明らかにした。したがって、3. 半無限長さ〜 4. 有限長さの杭基 礎にわたって、架構および杭長さを考虑した杭基礎の応力・変形を 一つの系として明らかにすることができた。

\section{5. 杭基碮の応力・变形の簡単な設計法}

ここでは、以上で明らかになった杭基礎の応力変形系を利用した 杭基磷の簡単な設計法を説明する。

Qo/yoを $q$ で、Mo/yoを $m$ で記号化する。架構の全ての杭基磷につ

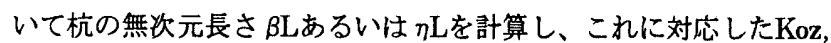
Koy,Komの值を図 7あるいは图8で求める。架構の隅基礎および中 基礎の $\omega$ を(5)〜 (8)式で求め、これらに対応する $\theta$ 值を $\beta$ 型地盤では 図1 (図9参照)、 $\eta$ 型地盤では図2 (图10参照)で読みとる。各基 礎についてそれぞれのKoz,Koyおよび日. 值を(11)あるいは(13)式 に代入すると $q$ 值が得られる。q值は単位が $\mathrm{kN} / \mathrm{m}$ であって杭頭に おける水平力分担定数にあたる。架構の全ての杭のq值の合計を $\Sigma q$ で記号化する((17)式)。ここにn：全基礎数である。 $q / \Sigma q か ゙$ 杭頭の 水平力分担率であって、これを基礎全体に作用する水平力の值Q に乗ずれば、各杭が負担する水平力の大きさQ。が(18)式で得られる。 杭頭の水平变位量yoは全ての杭頭部で等しいので、任意の杭のQo および $q$ 值によって(19)式で求められる。一方、Moは、 $\theta$ 值および Koy、Kom值を(12)あるいは(14)式に代入してmを求め、これにyo を乗じて得られる((20)式)。なお、基礎の回転角 $\theta 0$ は、 $\theta=\theta 0 /(y o \beta)$ あるいは $\theta=\theta 0 /(y o n)$ を変形した(21)式あるいは(22)式で求められ る。

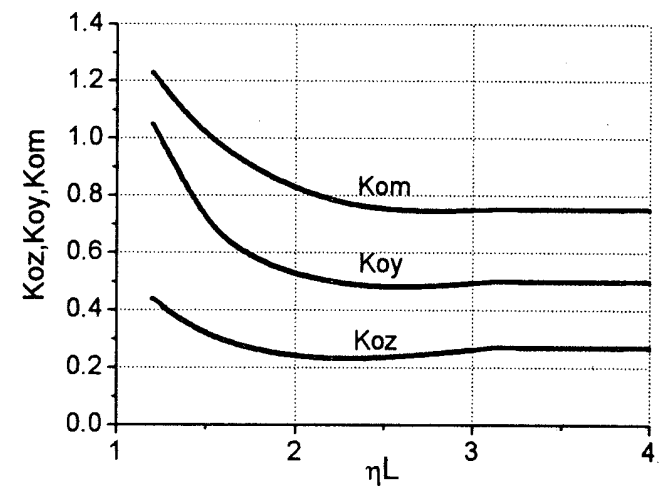

図 8 Koz、Koy、Kom $-\eta \mathrm{L}$ 関係 $(\eta$ 型地盤 $)$

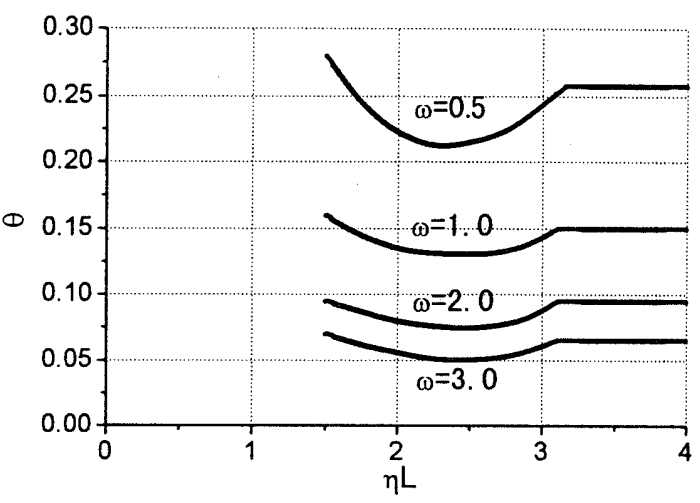

図 $10 \quad \theta-\eta \mathrm{L}$ 関保 $(\eta$ 型地盤） 
表 1 簡単な設計法による杭基礎応力変形の計算例 $-\eta$ 型地盤の場合一

\begin{tabular}{|c|c|c|}
\hline 項 & 隅 基 礎 & 中 基 礎 \\
\hline 杭 (PC杭) D, L, $\mathrm{E}_{\mathrm{p}}, \mathrm{I}_{\mathrm{p}}$ & $0.8 \mathrm{~m}, 20 \mathrm{~m}, 4,000 \mathrm{kN} / \mathrm{cm}^{2}, 0.0153 \mathrm{~m}^{4}$ & $0.8 \mathrm{~m}, 20 \mathrm{~m}, 4,000 \mathrm{kN} / \mathrm{cm}^{2}, 0.0153 \mathrm{~m}^{4}$ \\
\hline 地盤 (砂質) $\mathbf{n}_{\mathbf{h}}, \eta$ & $2,200 \mathrm{kN} / \mathrm{m}^{2}, 0.324 \mathrm{~m}^{-1}$ & $2,200 \mathrm{kN} / \mathrm{m}^{2}, 0.324 \mathrm{~m}^{-1}$ \\
\hline 無次元杭長さ $\eta \mathrm{L}$ & 6.48 & 6.48 \\
\hline スパン数、 $\mathrm{K}_{\mathrm{g}}, \mathrm{E}_{\mathrm{c}}, \mathrm{Q}_{\mathrm{all}}$ & 3 スパン、 $0.0055 \mathrm{~m}^{3} 、 2,100 \mathrm{kN} / \mathrm{c}$ & $\mathrm{A}^{2}, 400 \mathrm{kN}$ \\
\hline Koz,Koy,Kom (図8より) & $0.27 、 0.50,0.75$ & $0.27 、 0.50,0.75$ \\
\hline$\omega \quad((7),(8)$ 式より) & $2100 \times 0.0055 /(4000 \times 0.0153 \times 0.324)=0.58$ & $0.58 \times 3.2=1.86$ \\
\hline $\begin{array}{ll}\theta & \text { (図2, 図10より) } \\
\end{array}$ & 0.23 & 0.11 \\
\hline$q \quad((13)$ 式より $)$ & $(2 \times 0.27-0.5 \times 0.23) \times 2 \mathrm{E}_{\mathrm{p}} \mathrm{I}_{\mathrm{p}} \eta^{3}=0.85 \mathrm{E}_{\mathrm{p}} \mathrm{I}_{\mathrm{p}} \eta^{3}$ & $0.97 \mathrm{E}_{\mathrm{p}} \mathrm{I}_{\mathrm{p}} \eta^{3}$ \\
\hline$\Sigma q \quad((17)$ 式より) & $(0.85+0.97+0.97+0.85) \times 2 \mathrm{E}_{\mathrm{p}} \mathrm{I}_{\mathrm{p}} \eta^{3}$ & $3.64 \mathrm{E}_{\mathrm{p}} \mathrm{I}_{\mathrm{p}} \eta^{3}$ \\
\hline Qo （(18)式より) & $400 \times 0.85 / 3.64=93.4 \mathrm{kN}$ & (解析值 : $106.4 \mathrm{kN})$ \\
\hline yo ((19)式より) & $93.4 / 0.85 \mathrm{E}_{\mathrm{p}} \mathrm{I}_{\mathrm{p}} \eta^{3}=0.0053 \mathrm{~m}=0.53 \mathrm{~cm}$ & 解析值 : $0.51 \mathrm{~cm}$ ) \\
\hline$m \quad((14)$ 式より $)$ & $(-0.5+0.75 \times 0.23) \times 2 \mathrm{E}_{\mathrm{p}} \mathrm{I}_{\mathrm{p}} \eta^{2}=-0.655 \mathrm{E}_{\mathrm{p}} \mathrm{I}_{\mathrm{p}} \eta^{2}$ & $-0.835 \mathrm{E}_{\mathrm{p}} \mathrm{I}_{\mathrm{p}} \eta^{2}$ \\
\hline Mo ((20)式より) & $-0.655 \mathrm{E}_{\mathrm{p}} \mathrm{I}_{\mathrm{p}} \eta^{2} \times 0.0053=-223 \mathrm{kNm} \quad($ 解析値 : $-227 \mathrm{kNm})$ & (解析值 : -286 ) \\
\hline (図4より) & 0.32 & 0.27 \\
\hline $\mathrm{M}_{\mathrm{m}} \quad((10)$ 式より $)$ & $0.32 \times 93.4 / 0.324=92 \mathrm{kNm}$ & （解析値 : 89kNm) \\
\hline$\eta \mathrm{L}_{\mathrm{m}}$ (図6より) & 1.9 & 2.1 \\
\hline $\mathrm{L}_{\mathrm{m}}$ & $1.9 / 0.324=5.9 \mathrm{~m}$ & $2.1 / 0.324=6.5 \mathrm{~m}$ （解析值 : $6.5 \mathrm{~m}$ ) \\
\hline
\end{tabular}

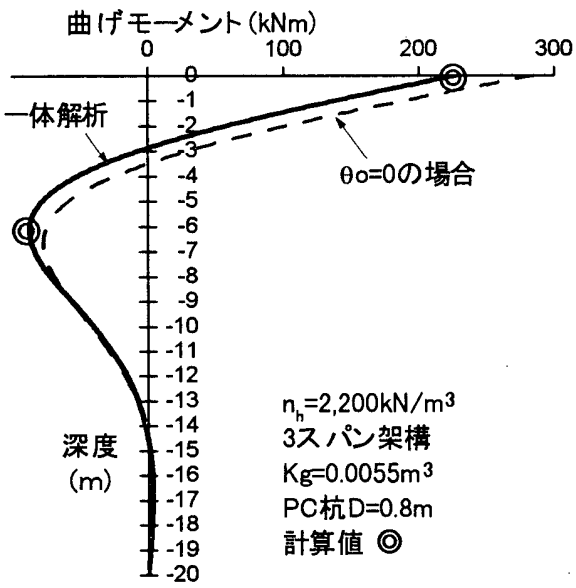

図 11 隅基礎の曲げモーメント

$$
\begin{aligned}
& \Sigma q=q_{1}+q_{2}+\cdots+q_{\mathrm{i}}+\cdots+q_{\mathrm{n}} \\
& \mathrm{Qo}=\mathrm{Q} \text { all } \times q / \Sigma q \\
& \text { yo }=\mathrm{Qo} / q \\
& \mathrm{Mo}=m \times \text { yo } \\
& \theta \mathrm{o}=\theta \times \text { yo } \times \beta \\
& \theta_{\mathrm{o}}=\theta \times \text { yo } \times \eta
\end{aligned}
$$

この設計法では、杭頭の水平力值、曲げモーメント值、地中部最 大曲げモーメント值とその発生深さおよび杭頭での水平変位量だけ が得られる。表 1 に一例を挙げて、この設計法による計算順序と計 算による応力・変形值を示し、これらのうち隅基礎について、曲げ モーメント值を図11に、杭頭水平変位を図12に@で示した。中 基礎の図は省略した。本例は $\eta$ 型地盤であって、架構剛性および杭 基礎が一定の場合である。比較のため一体解析による值を実線で併 記してある。Qo、Mo、M $\mathrm{M}_{\mathrm{m}}$ 值および $\mathrm{L}_{\mathrm{m}}$ の計算による值は一体解析值 によく一致した。さらにもう一例として、杭長さが異なる場合の杭 基礎の応力を本設計法で求め、曲げモーメント値を@で図 13 に示 した。杭長さが異なる場合にも本計算法による值が一体解析の値と よく一致することを示せた。これまでは架構を考慮した杭基礎の応 力変形は精算法でしか求められなかったが、本報で杭基礎の応力・ 変形を一つの系として明らかにしたことによって、簡単で精度のよ

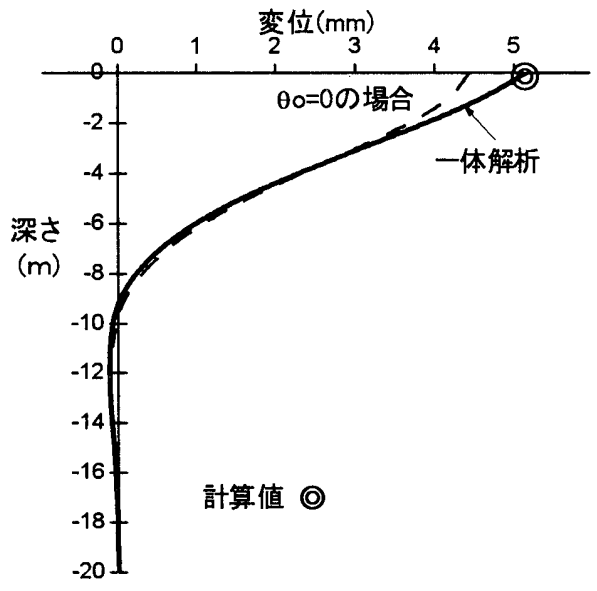

図 12 隅基礎の水平変位

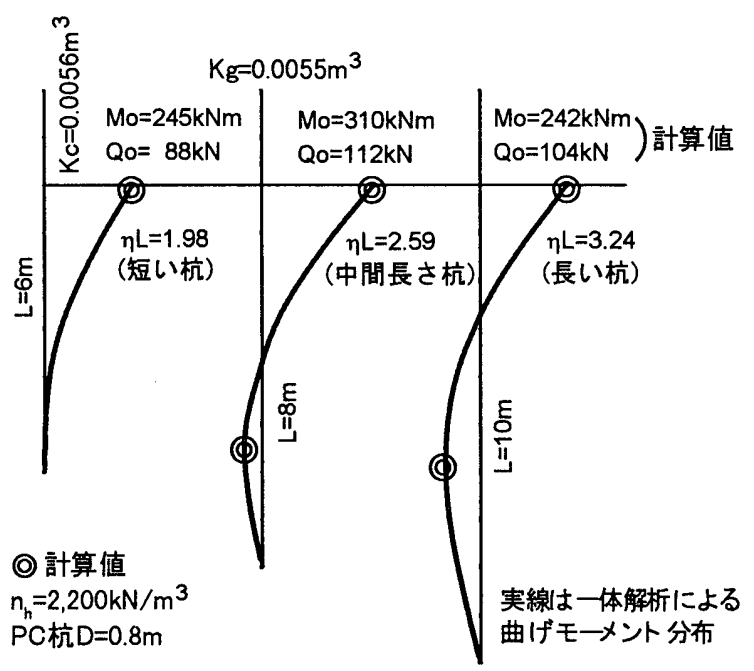

図 13 杭長さが異なる場合の応力計算値

い設計法が示せた意義は大きいと思う。ただし、基礎閒の相対沈下 が大きい場合は、精算法での一体解析を行う方がよい。

参考のために、架構の基礎まわりの部材端部曲げモーメントの設 計法を以下に述べておく。まず任意の $\mathrm{i}$ 基礎の回転角を $\theta 0$ とする。 その左右に位置する基礎の回転角は、それぞれサフィックスを付け 
て $\theta \mathbf{o}_{(\mathrm{L}) 、} \theta \mathbf{o}_{(\mathrm{R})}$ で区別する。 $\theta \mathbf{o}_{(\mathrm{L}) 、} \quad \theta 0$ および $\theta \mathbf{o}_{(\mathrm{R})}$ は(21)あるいは(22)

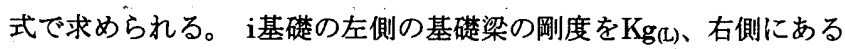
基礎梁の剛度を $\mathrm{Kg}_{(\mathrm{R})}$ で区別する。さらに、i基礎の左側の基礎梁端 部曲げモーメントを $\mathrm{Mg}_{(\mathrm{L})}$ 、右側の端部曲げモーメントを $\mathrm{Mg}_{(\mathbb{R})}$ で区 別しておく。基礎間に相対沈下がない場合のたわみ角法の式((23) および(24)式)に $\theta \mathrm{o}_{(\mathrm{L}) 、}, \theta \mathrm{o} 、 \theta \mathrm{o}_{(\mathrm{R})}$ 値を代入すると、 $\mathrm{Mg}_{(\mathrm{L}) 、} \mathrm{Mg}_{(\mathbb{R})}$ が得 られる。また、1 階柱脚曲げモーメントMcはi基礎節点における曲 げモーメントの鈎合いから(25)式で求められる。この方法による基 礎梁曲げモーメント值なども一体解析の值とよく一致するが、各図 が煩雑になるので記載は省略した。

$$
\begin{aligned}
& \mathrm{Mg}_{(\mathrm{L})}=2 \mathrm{EcKg}_{(\mathrm{L})} \times\left(2 \theta o+\theta o_{(L)}\right) \\
& \mathrm{Mg}_{(\mathrm{R})}=2 \mathrm{EcKg}_{(\mathrm{R})} \times\left(2 \theta o+\theta o_{(R)}\right) \\
& M c=-\left(\mathrm{Mg}_{(\mathrm{L})}+\mathrm{M}_{(\mathbb{R})}+\mathrm{Mo}\right)
\end{aligned}
$$

\section{6. 結論}

杭と架構を一体とした精算法による弾性解析 (一体解析と略称)を 架構剛性や杭剛性などを種々組み合わせて約220例行い、架構をも った杭基礎 (杭基礎と略称)の応力変形を、杭種、杭長さ、架構など を限定しない一つの系として明らかにした。1 柱 1 杭形式で杭頭が 基礎に剛結された杭 (基礎が回転すれば杭頭が同一の回転を生じる) であって、基礎間の相対沈下はないものとした。地盤は一層地盤で あって、地盤の水平反力係数 $\mathrm{k}_{\mathrm{h}}$ を一定值で表す場合を $\beta$ 型地盤 $(\beta=$ $\left(k_{h} D /\left(4 E_{p} I_{p}\right)\right)^{0.25)}$ と呼び、 $k_{h}$ が深さに比例する場合 $\left(k_{h}=n_{h} \times x / D 、\right.$ ここに $\mathrm{n}_{\mathrm{h}}$ : 定数 $)$ を $\eta$ 型地盤 $\left(\eta=\left(\mathrm{n}_{\mathrm{h}} /\left(\mathrm{E}_{\mathrm{p}} \mathrm{I}_{\mathrm{p}}\right)\right)^{0.2}\right)$ と呼んだ。

（1）杭基礎の一般特性は、基礎が基礎梁で慗がれているため、杭 頭応力の絶対量ではなく単位水平変位あたりの值に特性が現れる。 弾性支承梁理論解((1) (4)式) から、半無限長さ杭基礎のQo/yo、Mo

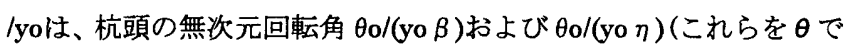
記号化した)によって変化することを指摘した。ここに、Qo：杭頭 に生じる水平力、Mo：杭頭に生じる曲げモーメント、yo : 杭頭水平 変位および $\theta \mathbf{o}:$ 杭頭回転角である。

（2）半無限長さ杭基礎に関する一体解析結果の $\theta$ 值は、基礎に集 まる基礎梁の曲け剛度の和（隅基礎：EcKg、中基礎： $\Sigma \mathrm{EcKg}$ ）と杭

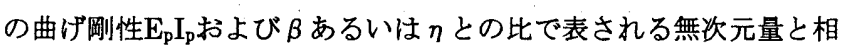
関性が高かった。この無次元量を山で記号化し、(5)〜(8)式で表し、 杭頭の回転拘束度と称した。 $\omega$ を表す要素に 1 階柱剛度を含めてい ない理由は、 $\theta$ 值に対して 1 階柱剛度はほぼ一定値として関与して いるためである。 $\theta$ 值は隅基礎と中基䃈で大きく異なったので、こ れは杭頭回転拘束度が異なるためとみて、中基礎には拘束効果の重 み1.6を乗じて $\omega$ 式を示した。この $\omega$ 式を用いることによって隅基礎 と中基碟の $\theta-\omega$ をひとつ曲線で表現できた (図1、図2の実線)。

(3) 半無限長さの杭基礎について、地中部最大曲げモーメント $\mathrm{M}_{\mathrm{m}}$ をQoと変数cを用いた式で表し((9)、(10)式)、一体解析によって得 た $\mathrm{M}_{\mathrm{m}} 、 \mathrm{Q}$ 值からc值を求めて $\mathrm{c}-\omega$ は一義的な関係であることを示 した(図3、图4の実線)。

（4）半無限長さの杭基磷の $\mathrm{M}_{\mathrm{m}}$ の発生深さ $\mathrm{L}_{\mathrm{m}}$ も体解析で求め、 無次元量 $\beta \mathrm{L}_{\mathrm{m}}$ および $\eta \mathrm{L}_{\mathrm{m}}$ と $\omega$ が一義的関係であることを示した（図 5、图6の実線)。

以上、半無限長さの杭基礎の応力・変形值は杭頭回転拘束度 $\omega$ の みによって決まることを示した。
（5）有限長さ杭基礎のQo/yo、Mo/yoは、係数Koz,Koy,Komと $\theta$ で変化することを指摘した ((11)〜 (14)式)。

(6) 㐿数Koz,Koy,Komはそれぞれ無次元杭長さ $\beta \mathrm{L}$ あるいは $\eta \mathrm{LK}$ よって一義的に決まる值である(図 7、図8)。Koyと無次元杭長さ の関係から弾性理論における杭長さの区分を明らかにした。 $\beta$ 型地 盤では半無限長さ相当杭： $\beta \mathrm{L}>2.5$ 、中間長さ杭 : $1.6<\beta \mathrm{L}<2.5$ 、 短い杭： $\beta \mathrm{L}<1.6$ である。 $\eta$ 型地盤では、半無限長さ相当杭： $\eta \mathrm{L}>$ 3.1 、中間長さ杭 : $2.0<\eta \mathrm{L}<3.1$ 、短い杭： $\eta \mathrm{L}<2.0$ である。

（7）有限長さ杭基礎について一体解析を行って $\theta$ 値を求め、 $\theta-$ 山は一義的な関係であることを示した(図 1、図 2 に破線で併記)。

（8） $\omega$ 一定の場合、 $\theta-\beta L$ 関俰および $\theta-\eta \mathrm{L}$ 関係はほぼ杭長さ の区分に従って変化することを示した(図9、图 10 )。

（9）有限長さ杭基䃈の地中部最大曲げモーメント $\mathrm{M}_{\mathrm{m}}$ を前述の(9)、 (10)式で表し、一体解析によって得た $\mathrm{M}_{\mathrm{m}}$ 、Qo值からc值を求めた。 cは山と一義的な関係であった(図 3、图 4 に破線で併記)。 $\mathrm{M}_{\mathrm{m}}$ の 発生深さ $\mathrm{L}_{\mathrm{m}}$ の無次元量 $\beta \mathrm{L}_{\mathrm{m}} 、 \eta \mathrm{L}_{\mathrm{m}}$ もそれぞれ、無次元杭長さおよ び山との一義的な関俰として示せた（図 5、図6に破線で併記）。

（1０）したがって、有限長さ杭基磁の応力・变形值は、無次元杭 長さと杭頭回転拘束度 $\omega$ によって决まる值である。

以上、半無限長さ〜有限長さの杭基礎の応力変形特性を、杭種を 限定しない一つの忘力変形系として明らかにした。

（1 1 1) この杭基礎の応力変形系を利用した杭基礎の応力、变形の 簡単な設計法を説明し、2 例を試算し、この简単な設計法によって 精度よい忘力変形値が得られることを示した(表 1 、図 11 、図 12 、 图 13 )。

\section{参考文献}

1)建築基礎構造設計指針, 日本建築学会; pp. $250 \sim 252,1988.1$ 2)中澤瑤子，山肩邦男 : 上部架構を考慮した杭基礎の水平抵抗につ いて, 第18回土質工学研究発表会, pp.1051 1054, 1983.6 3)武藤清 : 耐震設計法シリーズ 1 , 丸善, pp.107〜109, 1963 4)中澤瑤子，山肩邦男：上部架構を考虑した群杭基礎の水平抵抗理 論解, 日本建築学会構造系論文報告集, No.389, pp.132 143, 1988.9

5)中澤粨子, 山肩邦男 : 上部架構を支持する基硠杭群の崩壊過程, 第2 7 回土質工学研究発表会, pp.1663 1666, 1992.6

6)中澤璠子, 山肩邦男 : 杭長さの異なる杭基礎における水平荷重時の 崩壊過程，日本建築学会大会学術講演梗概集，pp.1321 1322, 1992.8 7)中澤璠子, 山肩邦男 : 粘性土地般における支持杭の終局水平抵抗 に関する解析的検討, 日本建築学会構造系論文報告集, 第454号, pp.85〜94, 1993.12

8)中澤粨子，山肩邦男：一方向水平力による杭基礎の終局水平耐力 之変形解析例, 第29回土質工学研究発表会, pp.1587 1590,

1994.6

9)中澤瑤子, 山肩邦男 : 架構剛性を考慮した群杭基䃈の水平荷重時 応力略算法, 日本建築学会構造系論文報告集, 第 404 号,

pp.129 134，1989,10

10)中澤璠子, 山肩邦男 : 群杭の剛性と杭頭固定度を考虑した架構の 応力解析例, 第21回土質工学研究発表会, pp.1201 1202, 1986.6 11)横山幸満 : くい構造物の計算法々計算例, 山海堂, p.34, 1985 12)横山幸満：〈い情造物の計算法と計算例，山海堂，pp.88〜93; 1985 13)B.B.Broms : Lateral Resistance of Piles in Cohesive Soils, Proc., ASCE, Vol.90, No.SM2, pp.27.63, 1964.3

14)B.B.Broms : Lateral Resistance of Piles in Cohesionless Soils, Proc., ASCE, Vol.90, No.SM3, pp.123-156, 1964.5

15)建築基礎構造設計指針，日本建築学会，pp.248～249，1988.1 16)横山幸満 : くい構造物の計算法と計算例, 山海堂, p.53, 1985 